The Mainstream Democratic Vision

Donald E. Whistler, University of Central Arkansas

This work utilizes recent literature on the democratic experience to provide insight into the nature, institutionalization, and problems of mainstream democratic thought. Our innate needs motivate us to seek a decision-making system in which our self-interests are met most effectively. Democracy is a procedure for making binding collective decisions that permits each citizen to express self-interest by having some voice in decisions concerning matters that affect her/his life. Democracy has evolved from a system of citizens expressing their self-interest through direct participation to a system of expressing self-interests indirectly through representatives. Large populations of diverse interests necessitate indirect participation in the form of guaranteed individual rights to formulate and express preferences and to choose in free elections those who, under circumscribed procedures, will make public policies in response to citizens' preferences. Modern democracy institutionalizes individual freedom of choice in a competitive system of making binding collective decisions. It is the distribution of privately controlled resources that both provides the wherewithal to demand participation in binding collective decision-making and guarantees the competitive, accessible nature of the decision process. Belief in the democratic process may be the ultimate shared value that binds diverse groups together into a modern political community.

\title{
Introduction
}

The democratic process is a gamble on the possiblities that a people, in acting autonomously, will learn how to act rightly.

Dahl 1989, 192.

In summer 1989, millions of people were transfixed by the sight of a lone man facing a tank in Tiananmen Square. It was the specter of a human standing alone for an ideal in the face of overwhelming force. The young man stood for democracy against autocracy. He lost, overwhelmed, together with his band of cohorts, by brute force. Half a world away from Tiananmen Square, autocracies were disintegrating as the concrete wall that had succored them collapsed. In November, 1989, Jan Urban had called for national elections in Czechoslovakia. He was laughed at. A week later thousands of protesters filled Wenceslas Square and a general strike brought the collapse of the regime (Tarrow 1991, 12). By April 2, 1991, the last of the Eastern European regimes -- Albania -- held an open election. Yet on August 18, 1991, some members of the Soviet military and of the CPSU attempted a coup d' etat. Literally hundreds of thousands of Soviet citizens went to the streets to face the tanks. Their courage, plus that of their democratic leaders, prevented remonopolization of Soviet political power.

Since the end of World War II, democracy has become the universal symbol to accomplish the human desire for freedom and material well-being. We have come to believe that democracy is the most appropriate way to organize the collective decision-making system to best assure that our individual needs will be 
fulfilled simultaneously with our collective needs. The problem, of course, is how this is to be accomplished within a collective decision-making system that in the modern world involves millions of persons (within nation-states) making literally hundreds of thousands of collective decisions each year. Less than half of the earth's nations can be classified as democratic (Dahl 1989, 241; Vanhanen 1990, 33). As Jan Urban expressed it, knocking down the barbed wire was the easy part; now, the formidable task of building the institutions and values to sustain democracy remains (Tarrow 1991, 17).

Are humans "capable of establishing good government from reflection and choice, or ... forever destined to depend for political considerations on accident and force?" asked those who defended the new American Constitution of 1787 (Ostrom 1987, 14). To be sure, historical circumstances -- geography, ethnicity, economic conditions, etc. -- have much to do with determining what is the organization of a society. But under certain conditions humans may construct societal organizations to meet ideals that we have devised. Indeed, democracy owes its existence to what we believe collective decision-making is, can be, and ought to be: it is the interaction of our ideals with our experience of constructing institutions to implement our ideals that must be understood accurately if democracy is to survive (Sartori 1987, 12). In examining the interaction of ideals and their implementation, we should also understand the purpose and function of ideals, as well as the actual results of our democratic institutions in practice.

Moreover, we should appreciate that modern democracy does not result simply from expressions of human courage, but requires an array of supporting conditions and attitudes. Sadly, there have been many more Tiananmen Squares throughout history than Wenceslas Squares. The earth would long since have been cleared of oppression were it accomplished solely by human courage. Indeed, vast numbers have died in futile efforts to oppose tyranny. In the modern world, autocracies have ceased when economic, social, and coercive resources are widely enough distributed that no subset of the population can monopolize the government. When we humans are able to do so, most of us prefer to make decisions that affect our lives, or at least to meaningfully and voluntarily consent to others making these decisions on our behalf. That is, when we have the personal resources to act independently of others, especially of our government, we will demand a binding collective decision-making process in which we can meaningfully participate to protect our interests. And at some point, when enough of us possess sufficient resources, those who would monopolize the binding collective decisionmaking cannot do so. When this occurs, democracy may be born.

The term democracy is used to describe very different states of affairs (Vanhanen 1990,6). Beyond the general symbolic usage of the term to express a shared decision-making process that expresses the human desires for freedom and for material and social amenities, agreement on democratic ideals and their institutional implementation becomes less certain. Some of the confusion over the meaning of democracy is the result of different versions of the democratic vision; 
different prophets see different visions. Regrettably, some of the confusion also is the product of opponents' deliberate mislabeling and misuse of concepts (Sartori 1987, ix-xii). However, we have historical experiences to inform us of the visions that we have had of democratic ideals and of our efforts to construct institutions to implement the ideals. The vocabulary of politics consists of experience carriers -- terms such as freedom and democracy -- whose meanings incorporate historical learning (Sartori 1987, 506). Democracy can be defined and understood by the common usage of language, which over time has defined and redefined the term.

This work utilizes recent scholarship that has built upon accumulated experience to provide insight into the nature, institutionalization, and problems of mainstream democratic thought.

\section{The Democratic Vision}

Democracy is a project that we devise in our minds, consisting of a human vision of how we believe collective decision-making should be conducted, along with our experiences at constructing institutions to accomplish these ideals (Sartori 1987, 12-18). The ultimate western value has been freedom of choice -- that it is for each individual to choose what she/he wants. The democratic vision has evolved from implementation as direct participation in the making of binding collective decisions to a more limited but more realistic operationalization as indirect participation through choosing those who will -- under very carefully circumscribed procedures -- govern us.

Democracy organizes society upon the principle of individual freedom of choice. In exercising freedom of choice, the individual has the opportunity to develop herself/himself most fully, and the society which results has the greatest probability of maximizing shared values as well as socioeconomic development.

The democratic vision is based on the common human desire to make decisions that affect our personal interests, or at least to consent voluntarily and meaningfully to decisions made by others on our behalf. The democratic vision assumes that all humans are of equal intrinsic worth, that "no person is intrinsically superior to another" (Dahl 1989, 85). In terms relevant to collective decisionmaking, this means that within the limits of feasibility, "the interests of every person who is subject to the decision must be accurately interpreted and made known" (Dahl 1989, 86). Therefore, all citizens should participate in public decision-making because no one knows better than each of us what our interests are. Each citizen must be assumed to be the best judge of her/his interests unless there is compelling evidence to the contrary, as would apply in the case of children and the mentally deficient. Indeed, there is no evidence that there exists either a set of persons who have special competence to make political decisions, or a body of special knowledge of governance that would justify limiting participation to those who have mastered that knowledge (Dahl 1989, 65-75).

To reiterate, our self-interest motivates us to know our own interests 
better than anyone else will know our interests. Our interests are what we choose "with the fullest attainable understanding of the experience resulting from that choice and its most relevant alternatives" (Dahl 1989, 180). And accumulated experience demonstrates that it is necessary for us to be citizens -- to participate in decisions affecting our interests -- if our interests are to have any assurances of being considered. The democratic process thus becomes required to implement these principles. The "democratic process is the surest, but not certain, way we humans can protect our interests and goods" (Dahl 1989, 311). And it thus may be the ultimate shared value that produces community from among the many.

\section{The Vision of Democratic Society}

Our experiences to date demonstrate, however, that while all democratic proponents base their visions upon human freedom of choice, there are different versions of what this constitutes. On one end of a mainstream democratic continuum (Figure 1) are those who will say freedom of choice is what adult humans choose for themselves that the democratic process has not defined as inappropriate, and thusillegal (Friedman and Friedman 1980; Hayek 1957; Nozick 1974). We might name this the straightforward freedom of choice approach. On the other end of the mainstream democratic continuum, there are other democrats who envision that freedom of choice will or should result in humans choosing what is ultimately best for any human. Such consists of a hierarchy of values and conduct that constitutes human self-development. Some of these see a purely secular vision of the self-developed human (e.g., Bay 1970); some of these have a religious basis for the ultimate human development (e.g., Simon 1962). We might name this polar type on our continuum freedom of choice through self-development. Of course there are degrees of difference within each of the polar types, as well as a range of intellectual positions between them. A conceptual type that would fall between the poles would be those who would promote political equality by means of governmental actions to redistribute the resources that are necessary for political equality to be exercised (e.g., Dahl 1989; Rawls 1971).

Figure 1. Continuum of Mainstream Democratic Thought

Straight forard
Freedom of
Individual
Choice

Some Equalization

of Socio-economic

Resources to Enhance

Political Equality
Self-Choice

Through

Self-Development

The democratic vision of the organization of society is to maximize human potential for self-choice. But self-choice is not self-interpreting. Those who insist upon straightforward freedom of choice as the foundation upon which 
to construct social, economic, and political institutions require minimal government involvement/activity and maximum individual choice in economic and interpersonal relationships. This organization and operation of democratic government would maximize individual choices by restricting government in what it can do, and how it can do it (Friedman and Friedman 1980). Those on the other end of the continuum contend that in participating fully in the matters that affect our lives, we develop our various potentials as humans, aiming at the moral human who understands and internalizes the principles, behaviors, and rules required to maintain the best quality democratic community (Barber 1984).

Two interrelated conflicts emerge from these polar images of the democratic vision. First, how much government action is required, if any, to coerce equalities that provide resources for participation in the binding collective decision-making process? Secondly, don't efforts to provide some equalization of resources inevitably treat citizens unequally in the regard of rights? Liberty must be restricted by governmental coercion to enhance equality. Those who envision self-choice through self-development look into the democratic mists and see participation requiring a harmony of communal interests in which the individual expresses her/his freedom while participating in the process of making decisions binding upon all. A community must necessarily share interests and values to be a community, and this will require a set of resources common to most members. In this situation, liberty is the equal right to participate in making the binding decisions for the community (Barber 1984). Those democrats in between the polar types emphasize the need for government at least to distribute, if not redistribute, socioeconomic resources which enhance political equality and participation (Dahl 1989). Such efforts also confront the liberty-equality quandary: liberty suffers when governmental coercion is practiced to enhance equality. Efforts to use government to equalize resources (and, thereby, statuses) automatically involve at least some governmental coercion of interpersonal relations and of economic activities. Such actions -- indeed, any governmental activity that goes beyond minimal protections -- are perceived by straightforward freedom of choice advocates as socially oppressive and economically atrophic, however necessary and beneficial such distributive actions may appear to those at or near the opposite pole of the continuum.

\section{Liberty and Equality}

Liberty and equality are critical ingredients in the democratic vision of participating in collective decisions that affect us. Differences over the meaning and interaction of liberty and equality are fundamental to the differing visions of democracy. The straightforward freedom of choice version of liberty is the political-juridical concept which equates liberty and equality. This concept was the initial Greek idea that all citizens had equal legal political rights and obligations. Every citizen of the ancient Greek democracies had equal political 
rights to participate directly in the collective decision-making process and the obligation to do so. Equality and freedom were the same thing in this original, political-juridical concept; that is, each amounted to participation in public policy-making (Sartori 1987, 342-343).

Over time, several additional notions of equality have been devised. Chronologically, the next concept to emerge was that of social equality. It is the equal power to privately resist social discrimination -- to join or not join some grouping if one chooses and is privately able. In other words, one is not ascribed to social status by a legally enforced class structure. Next, an equal access concept of equality developed. It is the equal opportunity to develop one's own talent. The fourth in the sequence of conceptualizations of equality is equal starts. It wants to assure adequate initial material conditions to enable one to access opportunities for the development of one's talent. Finally, economic sameness for all, including dispossession and state ownership, is the latest in the sequence of conceptions of equality (Sartori 1987, 342-347).

Achieving the first three concepts of equality (political-juridical, social, and equal access) do not require government to act. But the latter two concepts (equal starts and economic sameness) do require government to act, specifically by treating citizens unequally to achieve the desired egalitarian results. Equal starts, at the very least, require distributive public policies, such as progressive income taxes. Economic sameness requires governmental dispossession of the citizenry, that is, no significant amounts of private property. The politicaljuridical concept of equality not only occurred first chronologically but it is also the prerequisite to the other equalities (Sartori 1987,351-353,397). Furthermore, economic sameness (the fifth concept of equality) is outside the parameters of mainstream democratic theory (Dahl 1989, 80; Riker 1982, 7; Sartori 1987, 345347). No modern system has been able to maintain a democratic political structure if it has eliminated significant amounts of private property from its citizenry (Riker 1982, 7).

\section{Implementing Democratic Ideals: The Basic Institutional Experiences}

Our experiences with building political structures to implement democratic ideals have occurred during two basic transformations: 1) the direct democracies of the early Greeks, and 2) the modern representative democracies that have developed since the 1600s. That all are equal politically (power to the people) was at first implemented (in ancient Greece) by direct participation of citizens in public policy-making. This was not possible with the larger populations present during the later transformation. Representative institutions were converted from monarchical use to democratic use, but with restraints to control the arbitrary use of political power, a fault of the Greek democracies as well as of all other forms of government (Sartori 1987, 287, 290). 
The modern representative democracies must function within huge, diverse populations where everyone is pursuing her/his self-interest and where, consequently, participation is protected by restraints upon government (civil liberties -- guarantees of what government is not to do) and by civil rights (guarantees that citizens have as citizens). Representative democracy changes the fundamental democratic ideal, from power to the people exercised as participation in public decision-making, to power to the people exercised as the election of others to make decisions for them. Elections thus became the power of the people to control their elected officials, albeit necessarily infrequently held. And, the democratic ideal changed to "all power to no one" in public office through rule of law guarantees (Sartori 1987, 71-72).

The theory and practice of modern democracies are based upon our experiences with these two transformations of democracy. For several hundred years, we have struggled to integrate direct participatory democratic structures with representative democratic structures. Some thinkers have continued to insist that representative institutions cannot be democratic, that the power of the people only is in direct participation (Rousseau); others have attempted to integrate these two types of institutions emphasizing participatory structures (Barber 1984); others have sought structural accommodations with representative institutions predominant, but subject to rule of law (Dahl 1989; Sartori 1987).

\section{Mainstream Democratic Thought}

Participation, liberty, and equality are the concepts common to the spectrum of mainstream democratic thinking. Each of these three concepts, however, has acquired a double meaning (Riker 1982, 4-8). One meaning is instrumental to self-choice, in that it affects some aspect of self-choice. The other is an inherent self-development quality, inasmuch as each of the three concepts is an aspect of human self-development. The instrumental meanings are implemented by representative democracy, while in principle the self-development meanings are more fully implemented by direct participatory democracy.

To illustrate, participation is necessary to express self-choice. It has two meanings: 1) one may participate by voting (or running for office), thereby participating in the determination of who is elected, and thus in control of the government. This is participation's instrumental meaning. Participation is effectuated by voluntary conventional political activities. 2) Participation's second meaning is that one may participate as an expression of self-development. To wit, Aristotle wrote of the highest practical human activity being participation in public decision-making. In ruling and being ruled, the height of human potential is exercised. Participation is thus an end in itself. It is the expression of human dignity and self-development. Clearly, participation in representative democracy is limited, for most citizens, to voting in periodic elections among those competing for office. In direct democracies, on the other hand, participation in all decisions 
is had by each citizen, and is presumably therefore more efficacious for selfdevelopment.

Freedom, or liberty, is the second feature common to mainstream democratic thinking (Riker 1982,6). Its instrumental meaning is the capacity to pursue one's choices. Freedom renders political participation effective by protecting individuals' choices. And, while this is largely conceived in terms of voting, there is an array of civil liberties intended to guarantee individuals free pursuit of their choices. But freedom also has a second meaning. Freedom has become an end in itself: self-development for each individual. The good human requires freedom to develop the self into a morally autonomous person who, in making choices, considers the needs and interests of others including the larger democratic process's requirements (Dahl 1989, 311). In representative democracies, voting in periodic, meaningful elections is the instrumental rendering of freedom. Civil rights protect the individual's choice among competitors for public office and civil liberties prevent the government from unreasonably abridging the individual's free practice of the various activities needed to formulate and signify their choices (Dahl 1971, 3). Direct democracy, on the other hand, implements freedom as participation in the process of public decision-making (the second meaning of participation). To be free is to participate in societal law-making (Riker 1982,11-12). Indeed, such participation is the most vital manifestation of self-development.

The third feature common to the mainstream democratic vision is equality. The instrumental meaning of equality is that all citizens' votes are equal. This is required to make participation and voting effective. Equality is, at the same time, an aspect of self-respect and self-development. Serious economic and/or social inequalities deny opportunity for participation in societal decision-making, thereby hindering, perhaps preventing, opportunity for self-development. In representative democracies, the elected officials may enact regulatory, distributive, and redistributive public benefits to equalize circumstances in response to the periodic demands of voters. However, direct democracy involves an attitude of community which subsumes more comprehensively shared (relatively equal) life circumstances (Riker 1982, 7-8).

The ancient direct democracies were set amid small, homogeneous populations. They were, in principle, based upon civic duty and concern for the public good. In practice, however, they were factious (Dahl 1989, 21) and prone to tyranny by the majority (Sartori 1987, 290). There were no restrictions on the sovereign will of the people to do whatever they chose. For 2000 years democracy fell into disuse both because populations had become too large for direct democracies and because they were prone to majority tyranny (Sartori 1987, 287290). It was the grafting of liberalism upon democracy that salvaged and resurrected democracy as liberal democracy. It is a tenuous graft, in that whereas democracy is concerned with expressing the will of the people, with equality and results, liberalism is concerned with freedom, with individual initiatives, with 
controls and restraints upon political power (Sartori 1987, 380-386).

Modern liberal democracy was devised to implement the innate human desire to pursue our own self-interest by making decisions that affect our lives, or at least to consent voluntarily and meaningfully to collective decisions that affect us. Of course humans have always pursued self-interest. But in ancient Greece, human self-interest was much more closely tied to the group (tribe), which provided survival and which required close cooperation. Diversity and exercise of individual conscience were threats to the unity of the group, and therefore were threats to survival (Sartori 1987, 292). With the development of huge nation-state populations of diverse interests, the implementation of human self-interest changed from participation within one's group to enhance its survival (and thereby one's self-interest), to protection of the exercise of each of our individual selfinterests. Set amid the mass populations of nation-states where conflict and adversarial relationships inhere with the diversity of interests, the modern democratic process necessarily becomes a "bundle" of rights, procedures, and institutions that protect individuals' rights to exercise free choice in the making of binding collective decisions within large-scale political systems (Dahl 1989, 175).

\section{Democratic Criteria}

To be democratic, any set of institutions must meet some democratic criteria that operationalize the fundamental assumption justifying a democratic order, which is that binding decisions should be made by those subject to the decision. Dahl (1989) suggests five democratic criteria against which to evaluate any modern association.

1. Effective Participation. Throughout the process of making binding decisions, citizens ought to have an adequate opportunity, and an equal opportunity, for expressing their preferences as to the final outcome. They must have adequate and equal opportunities for placing questions on the agenda and for expressing reasons for endorsing one outcome rather than another (109).

2. Voting Equality at the Decisive Stage. At the decisive stage of collective decisions, each citizen must be ensured an equal opportunity to express a choice that will be counted as equal in weight to the choice expressed by any other citizen. In determining outcomes at the decisive stage, these choices, and only these choices, must be taken into account (109).

3. Enlightened Understanding. Each citizen ought to have adequate and equal opportunities for discovering and validating, within the time permissible, that choice (on the matter to be decided) which would best serve the citizen's interest (112). 
4. Control of the Agenda. The demos must have the exclusive franchise to decide how matters are to be placed on the agenda of questions that are to be decided by means of the democratic process (113).

5. Inclusiveness. The demos must include all adult members of the association except transients and persons proven to be mentally defective (121).

Dahl considers political processes that meet criteria one and two to be "procedurally democratic in the narrow sense." Processes that also meet the third criterion of enlightened understanding he regards as "fully democratic with respect to an agenda and in relation to a demos." And at a still higher level is the process that provides as well for final control of the agenda by the demos; it is "fully democratic in relation to its demos." But only the process that is inclusive enough to meet the fifth criteria is "fully democratic" (Dahl 1989, 130). Yet, while individuals must be able to participate if their interests are to be considered, since the Greeks it has been appreciated that not all in the demos are capable of knowing their interests, and that some identify and concern themselves not with this political system, but with some other. Some qualification must inform who is included as a citizen. Criterion 5 is such a qualification.

Political equality is achieved by the political process that meets the five democratic criteria. And, these criteria, which are neutral with respect to positions that could be taken on the continuum of mainstream democracy, could be implemented utilizing either the straightforward or self-development positions on the continuum (Figure 1). At the same time, while the five criteria do not equalize socioeconomic resources, Dahl insists that some equalization of socioeconomic resources is likely to be examined by those concerned with developing and sustaining the five criteria (Dahl 1989, 130-131).

\section{Types of Institutions Required to Implement the Democratic Criteria}

The five democratic criteria, when institutionalized, will permit citizens in a modern democracy to formulate and signify their preferences, and to have democratic government be responsive by equally weighing citizens' preferences (Dahl 1971, 2). This must take place amid the mass populations of modern nationstates. Dahl identifies as "polyarchy" the set of institutions that provide such opportunities to citizens in large-scale systems. He names them polyarchies rather than democracies because they do not fully implement the democratic ideals. (No political system does.)

Polyarchies are the result of longstanding efforts "to democratize and liberalize the political institutions of nation-states" (Dahl 1989, 218). Polyarchy distinguishes a different type of regime from the ancient direct democracies. It is a system of control of elected officials (government) by its citizenry through 
competitive candidates, parties, and groups; with the citizenry protected by a series of individual rights (218-219). In brief, the two basic ingredients are: 1) structures that provide free and fair competition among persons for public office, and 2) free and fair participation by citizens in choosing who shall temporarily occupy these elected positions. Polyarchy is a political order distinguished by the presence of institutions which perform the functions that implement the democratic criteria. These polyarchical functions are:

1. Elected officials. Control over government decisions about policy is constitutionally vested in elected officials.

2. Free and fair elections. Elected officials are chosen in frequent and fairly conducted elections in which coercion is comparatively uncommon.

3. Inclusive suffrage. Practically all adults have the right to vote in the election of officials.

4. Rights to run for office. Practically all adults have the right to run for elective offices in government, though age limits may be higher for holding office than for the suffrage.

5. Freedom of expression. Citizens have a right to express themselves (without the danger of severe punishment) on political matters, including criticism directed at officials, the government, the regime, the socio-economic order, and the prevailing ideology.

6. Alternative information. Citizens have a right to seek out alternative sources of information. Moreover, alternative sources of information exist and are protected by laws.

7. Associational autonomy. To achieve their various rights, including those listed above, citizens also have a right to form relatively independent associations or organizations, including independent political parties and interest groups (Dahl 1989, 221).

Different combinations of these seven types of democratic institutional requisites can be shown to satisfy each of the five criteria of the democratic process.

\section{Constructing Democratic Institutions}

While polyarchy is the set of modern institutional requirements to implement the five democratic criteria, the specific structure and legal powers of democratic governments -- legislatures, executives, courts, and bureaucracies -may differ from one democratic government to another. For example, parliamentary systems are quite different than presidential systems, and each such system numbers differences among its practitioners.

Whatever the specific democratic structures are, they must fulfill the democratic criteria. Figure 2 outlines the sequence. To illustrate, the first insti- 
Figure 2. Sequence of Democratic Elements

\begin{tabular}{|c|c|c|c|}
\hline $\begin{array}{l}\text { The } \\
\text { Democratic } \\
\text { Vision }\end{array}$ & $\begin{array}{l}\text { The } \\
\text { Five } \\
\text { Democratic } \\
\text { Criteria }\end{array}$ & $\begin{array}{l}\text { Institutional } \\
\text { Requirements } \longleftrightarrow \\
\text { (Polyarchy) }\end{array}$ & $\begin{array}{l}\text { Specific } \\
\text { Democratic } \\
\text { Governmental } \\
\text { Structures }\end{array}$ \\
\hline
\end{tabular}

tutional function of polyarchy -- control over elected officials - can be accomplished by different specific constitutional requirements, different terms of office, different specific positions, and different powers provided to legislatures, executives, courts, and bureaucracies. Similarly, the second insitutional requirement -- free and fair electoral systems -- is implemented by different specific electoral rules and procedures (e.g., the U.S.'s "winner-take-all" single-member electoral districts are different from the multi-member districts and proportional representation systems used in other countries). Likewise for the other types of institutional requirements necessary (polyarchies) to implement the five democratic criteria within large modern nation-states.

\section{Conditions Associated with Modern Democracies}

Historically, living under democracies has been an aberration. By the late 1980 s, less than half the nations of the planet were democracies. What type of social, economic, and historical "soil" nurtures democratic institutions and processes? Scholars since Aristotle have noted that democracy is associated with higher levels of economic development; some argue that higher national socioeconomic status produces higher probability of democracy (Vanhanen 1990, 37-46). Others specify a sequence of economic development and democracy: urbanization generates industrialization, which presses for literacy and a participatory societal order, with democracy as the "crowning institution of the participant society" (Daniel Lerner, quoted by Vanhanen 1990, 40).

Scholars also find that various conditions conducive to democracy are associated with national economic development. Multi-centered societies, along with certain attitudes (tolerance and trust of opposition) and democratic values (political equality, popular sovereignty), are associated with national socioeconomic development. Furthermore, having had certain historical experiences -- electoral competition prior to mass political participation -- are generally beneficial to democracy (Vanhanen 1990, 39-44).

But these national socio-economic characteristics, historical circumstances, and political cultural values are not uniformly related to democracy across all nation-states or regions of the planet (Pennock 1979, 206-254). Some African and Latin American cases have deviated from the associations predicted by the national economic development factor, as have Eastern Europe and the USSR. 
Particular historical and political cultural values have been offered as reasons for the deviations (Vanhanen 1990, 43-46).

No single condition can account for the existence of modern democracy in a country. However, Dahl $(1989,250-262)$ provides a set of conditions which are almost certain to facilitate polyarchy (i.e., the institutional requisites of modern democracy). The first condition for polyarchy even to be thinkable is that the coercive arms of the state -- the police and military -- must be under civilian control and should be decentralized. Civilian control is a necessary, but not sufficient, condition for polyarchy (e.g., under Stalin the CPSU controlled the USSR's military).

A second condition is a Modern Dynamic Pluralist country (MDP). Such a system is dynamic and has many autonomous social and economic groups (pluralism). Such systems are urban and industrial with higher education, health, and living standards. MDPs favor polyarchy because they disperse political resources, strategic locations, and bargaining positions. Nonetheless, inequalities of power (education, income, status) remain. A few countries have become polyarchies without MDP, thus MDP is not a sufficient condition.

A third condition of polyarchy is subcultural cleavages. As the strength of subcultures and antagonisms among them increase, polyarchy's chances decrease. Consociational democracy is one institutional effort to deal with subcultural cleavages. Consociational democracies are characterized by a grand coalition of political leaders, mutual vetoes of subcultures, subcultural representation in the Cabinet and other important units, and subcultural autonomy. Consociational democratic arrangements require political elites who favor it, which seems to be most likely in small countries where elites know each other. However, in countries that are culturally segmented, if activists do not perceive polyarchy as legitimate and if the political culture is not favorable toward democratic processes, then polyarchy is unlikely.

A fourth condition regards foreign influence or control. Domination by a foreign power that is inclined toward polyarchy (such as the U.S. in postwar Japan) increases polyarchy's likelihood. Work by Ryan (1992) suggests that this process may currently be at work in Central America. The other side of this coin is that domination by a foreign power hostile to polyarchy (e.g., the USSR in postwar Eastern Europe) will reduce polyarchy.

As Dahl observes, it is not simply a high level of economic development that is crucial to democracy. It is important that resources be distributed such that no set of citizens can monopolize coercive and socioeconomic sanctions (1971, 51). From Aristotle through Montesquieu and de Tocqueville to Dahl, the importance of the distribution of resources to democracy has been noted (Vanhanen 1990, 37-50).

Dahl maintained that the impetus toward polyarchy is provided when the costs of oppression rise higher than can be afforded by any set of would-be monopolizers of political power $(1971,16)$. Vanhanen $(1990,48-51)$ adds that 
democratic institutions, like any other societal arrangements, reflect the results of the struggle to survive. The scarcity of resources and the struggle to survive and reproduce have resulted in societal arrangements that are most effective at organizing this reality of life. Humans struggle for political power because it can be used to obtain life's necessities (and amenities). Democracy will become the method of organizing this pursuit of power when resources are distributed widely enough among groups and individuals to enable competitors for power to establish a system of competitive rules for participation in the making of binding collective decisions. "Democracy emerges as a rational compromise among strong competing groups" (Vanhanen 1990, 51).

The crucial condition for modern democracy is not that high economic development must be achieved, but that there must be a "balance of forces between competing groups, which prevents any competitor from achieving hegemony and makes the sharing of power necessary for them" (Vanhanen 1990, 195). Those taking the straightforward freedom of choice position on our continuum (see Figure 1) express a different opinion of how to accomplish this distribution of resources than those at the other pole.

\section{Major Problems with Democracy in Practice}

Democracy assumes political equality. All citizens should participate in binding collective decisions. Of course, this immediately encounters the problem of competence to make binding collective decisions. Clearly some qualifications are necessary. Children and those not concerned with the on-going system (citizens of another country) should not be participating citizens. But if a "criterion of competency overrides a claim to citizenship based upon rights, the argument for democracy is on mushy ground" (Dahl 1989, 126). The presumption of personal autonomy (each knows best her/his self-interest) is prudential. It is necessary to support political equality. At the same time, there is no evidence of a special set of persons, or a special set of knowledge that qualifies only a few to rule.

A second major problem is that the five democratic criteria do not specify a decision rule, i.e., the rule by which the group makes collective decisions. It turns out that several different rules are used to make decisions in modern democracies. Majority rule, however, must be the touchstone of a democratic decision rule because, although it has serious shortcomings, unless majority rule is the decision rule one must concede that the political institutions of nonmajoritarian countries may achieve the democratic process as fully as do political institutions in majoritarian countries (Dahl 1989, 152).

Regrettably, majority rule as a decision rule encounters the crucial problem that, in modern mass democracies, majorities at best are merely temporary aggregations on an issue. On some other issue, the aggregations or coalitions change. One moment one is with a majority on an issue, the next moment one is in the minority on another. What becomes critical is that individuals and minorities 
be free to express themselves. This requires restrictions on majority rule. Individual and minority rights must be protected by restrictions upon what majorities may do (Sartori 1987, 32-33). Limited majority rule protects the right to opposition. In fact, majority rule has not been majority tyranny in the U.S. because the multi-stage elections eliminate majorities along the way, and because majorities usually are not motivated by specific, intensely felt issues as are minorities (Sartori 1987, 133-147).

There are several technical and mathematical problems with majority rule as a decision rule (Riker 1982, 233-241). These problems render it impossible to determine if the sovereign will of the people has been converted into public policies by use of majority voting techniques. However, majority rule voting techniques can be meaningfully applied in elections in which citizens vote for competitors for a public office. In other words, voting is a meaningful method to implement the instrumental meanings of participation, liberty, and equality, but not to implement the intrinsic value of each of these concepts to self-development. The practical result, Riker concludes, is that liberal democracy is possible to accomplish using majoritarian voting techniques (1982, 241-253). Liberal democracy is where voters choose in free and fair elections among competitors for public office, and where those public offices in turn are restricted by constitutional rule of law as to their legal authority. Majority voting techniques can accomplish electoral democracy's requirements, but cannot identify and express either individuals' self-development, or the sovereign will of the people. Among majority rule's other outstanding shortcomings are that majority rule cannot determine what is morally right, or which people should be subject to a given political system (Dahl 1989, 151, 147-148).

This raises a third major problem area for democracy in practice -- the question of when a people should have their own independent political system. Majority rule cannot answer this question. Modern Croatians will not accept a majoritarian decision by Yugoslavia. Lithuanians wish to be a separate independent political system and, even if the USSR were a democracy, Lithuanians would not be prepared to accept a majoritarian decision from the USSR. It is not a solution to permit any group that wishes to call itself a political unit to do so. This would be self-chosen anarchy, or simple hegemony (one uses force to establish one's preferred political unit).

The claims and counterclaims of different groups to political sovereignty involve: 1) the scope of the political unit, i.e., things over which it makes decisions, and 2) the domain and/or size of the political unit (Dahl 1989, 193-197). Regrettably, majority rule does not provide an answer to these problems. (A majority of what set of persons?) Nor does the democratic process itself provide a complete method to answer these questions. Both majority rule and the democratic process presuppose the rightfulness of the political unit.

While violence and historical events frequently have determined which people shall have their own binding collective decision-making system, much can 
be said concerning the proper scope and domain of a democratic unit. First, the persons who comprise the political unit should be clearly bounded. Borders probably are needed or else jurisdictional disputes magnify. Second, these selfbounded persons should desire political autonomy over matters falling within their authority. Third, they should be committed to democratic processes. Fourth, the primary political rights of members of the bounded group should be protected. Fifth, members of the bounded unit should be significantly affected by decisions resulting from the jurisdiction under their authority. Sixth, the consensus among the members of the bounded unit should be higher than other boundaries would have produced. Seventh, overall, the gains should outweigh the costs (Dahl 1989, 206-208).

A fourth major problem with modern democracies in practice concerns the claim that democracy is a process that must produce certain results, i.e., that human progress, economic equality, and human rights must be advanced. Under this substantive interpretation of democracy, the democratic process frequently suffers from the making of claims against it. In the name of democracy, desired policies and results are claimed as essential to democracy. In fact, all citizens of all conditions have their wants and interests. The democratic process is the set of individual rights and procedures by which binding collective choices among these interests are made. It is not, then, a simple question of lofty substantive claims against "mere procedures." The democratic process is the package of primary political rights (civil liberties, civil rights, electoral processes, etc.) that protect the individual and by which his/her preferences are made known to those who will decide. It is, consequently, never appropriate to make substantive claims against the democratic process itself, i.e., against the primary political rights of the demos (Dahl 1989, 165-172).

A just process may produce an unjust outcome. The democratic process may do harm, or fail to achieve the common good. But, carried to extremes, insistence upon particular substantive outcomes would result in an anti-democratic guardianship or dictatorship. Those who contend that procedures should not be allowed to stand in the way of justice overlook that it is precisely because no guarantee of substantive justice can be made -- in a trial, for example -- that procedures are the only means of providing a fair trial (Dahl 1989, 163-164). Additionally, it is a serious mistake to claim that procedural democracy is mere "formality." Instead, the democratic process itself is a form of justice. The democratic process distributes authority and power, and these may (and do) distribute opportunities for wealth, status, knowledge, self-development and personal autonomy (deciding for yourself what is in your interest). Thus, the actual choice that is being made when substantive democracy is weighed versus procedural democracy "is between the justice of the democratic process, both procedural and distributive, and other claims to substantive justice" (Dahl 1989, 164).

Furthermore, it is not acceptable simply to declare that a democratic 
procedure is wrong without providing an alternative. Every procedure is certain to harm someone's interests. In Rawlsian terms, perfect procedural justice ("A procedure which can guarantee an outcome that we have independently defined as just ... [such as] a trial procedure that would always find the guilty to be guilty and the innocent to be innocent") is not possible. Only imperfect procedural justice -- a procedure that is the most feasible that we can design, though it sometimes may not produce the desired outcome -- is possible (Dahl 1989, 165).

In brief, only those interests integral and essential to the democratic process should be inviolable. The substantive desires of participants that are not primary political rights are matters to be decided by the democratic procedures (Dahl 1989, 182). Someone's interests are always harmed by binding collective decisions that all must obey. If alternative methods of decision-making are offered, such methods should demonstrate that over the long haul they will be superior to present procedures. Moreover, any guardianship or quasi-guardianship methods (e.g., judicial review) should be undertaken only with extreme precautions (Dahl 1989, 192). But first things first: what must always be foremost in mind is that democracy is a procedure which must come first. Substantive results are by-products derived from the procedures. They are in error who dismiss or degrade the requisite procedures and then insist upon substantive results (Sartori 1987, 1112).

A fifth problem of democracy needing attention is that of whether particular population charactistics require certain democratic structures. Here again we confront the problem of direct versus representative democratic structures. Modern advocates of direct democratic institutions simply do not admit the realities of population size. There are very severe limits on the number of persons who can gather in one place and speak. There are also severe limits on popular interest in and knowledge about public affairs, which advocates of direct democracy steadfastly refuse to acknowledge as inherent in the nature of public opinion (Sartori 1987,104-118, 123). The intensity required to sustain direct participation is, for the vast majority, a very temporary motivation. The daily press of other human needs and interests severely reduce the time and effort that most people are willing to invest in public participation. A modern direct democracy would require more than public opinion is capable of producing. The result of pursuing such democracy where it cannot be implemented would be domination by a vanguard of highly motivated activists (Sartori 1987, 113-114). Finally, the decentralization inherent in direct democracy would disrupt the coordination necessary to deal with those problems that transcend the boundaries of nations and bureaucracies, and would severely hamper defense against aggression.

In fact, western representative democracies have typically incorporated several different democratic structures. Indeed, it is necessary in devising a largescale political unit to utilize, where most efficient, several if not all of the possible democratic structures -- assemblies, committees, town or primary (direct) meetings, representative democracies, referenda, and non-democratic delegation of 
powers (Dahl 1990, 53-55). Mainstream democratic theory has always incorporated direct democratic structures at micro-levels below the macro-level of the polity (Sartori 1987, 113). However, direct democracies are logistically impossible above the level of small cities, perhaps impossible beyond small towns. At the macro-level, democracy can only be representative in structure, and, Sartori insists, the representative structure must be a liberal democracy -- an electoral democracy constrained by constitutional rule of law $(1987,114,323)$. If government is not democratic at the macro-level, then institutions below it cannot be democratic, either, even if structured for direct participation (Sartori 1987, 161).

A sixth important liability of modern democracy in practice is that functioning democracies fail to implement fully their democratic ideals. Consequently, there are constant efforts to reform or replace them. Marxists and their American idolators denounce as "formal shams" the current western democracies which they hope to replace. They rename equality as liberty and compare their own ideals to the actual practices of on-going democracies. They announce that western democracies are masks for self-interest, and in doing so, undermine belief in the ideas and institutions that western political experience has devised to protect human freedom (Sartori 1987, 497-503).

While those who seek to replace on-going democracies frequently misrepresent the nature and operation of western democracies, reformers of those democracies often naively expect too much of western democracies, or do not credit them enough for the extraordinary service that they have provided to humanity (Sartori 1987, 156-162). Reformers with perfectionist expectations often do not understand the purpose of ideals. Ideals are intended to serve as guides, not as actual implements (Sartori 1987,67-72). Indeed, ideals may beget inverted results when pushed to extremes: Jacksonianism and Progressivism each sought to increase popular participation in decision-making, but the overall effect of long ballots, more frequent, multi-stage elections (national-state-local multiplied by primary-runoff-general), and initiatives and referenda appears to have been to decrease voting turnout in American elections. Ideals are being misused when reformers turn a deaf ear to the evidence of how the ideals are working in practice. Furthermore, the utility of ideals changes with the circumstances to which they are applied. Perfectionists ignore this. With the change from small direct democracies to large representative democracies, the democratic ideal must change from power to the people through direct participation in decisions to power to the people through the election of representatives, who in turn must not be given all power. The new ideal must become "all power to no one" because what makes us free is to be protected from the arbitrary acts of our elected representatives, and this requires that restraints be placed upon what elected representatives can do (Sartori 1987, 321).

The misunderstanding of the nature and use of ideals often is the result of a rationalist approach to political thought. Rationalist thought, not realism, is 
the enemy of democracy. Realism merely inquires into what is the empirical state of affairs. But rationalism makes impossible the testing of results because rationalism begins with abstract principles and derives political institutions from the principles, regardless of the empirical results on humans. The resulting system is correct if it follows from the principles. Realism, on the other hand, constructs political institutions guided by ideals but founded on the basis of human experience. Realism accepts institutions as correct if they work properly in practice (Sartori 1987, 49-53).

Rationalism has great appeal because a few abstract principles are easier to grasp and communicate than are complex political experiences. One of the most appealing rational-type principles has been that we can apply to human affairs the same scientific methodology that has placed nature in service to humans. In fact, the intellectual appeal of Marxism has been this very idea that we can eliminate "politics" and make public decision-making an "administration of things" in which different science-based projects present themselves to neutral, selfless administrators who, like scientists, objectively choose the most scientifically efficient projects to advance humankind (Sartori 1987, 434-438).

Such thinking -- even without the Marxist component -- is wrongheaded. There are severe limitations on the extent to which scientific methodology is applicable to human decision-making. To be sure, experts are needed: in modern systems, intellectuals and others possessed of specialized knowledge are very important in public policy-making, whether they intend to be or not (Dahl 1989, 333-335; Sartori 1987, 423). However, for democracies the use of experts -including for planning -- must be limited to elected representatives choosing from among alternatives prepared by experts. Democracies are capable of making "small and middle range" decisions. Democracies cannot, however, "plan history." The more total planning is attempted, the less democracy is possible (Sartori 1987, 431-432).

A seventh problem area for democracies in practice is the "rule of legislators" (Sartori 1987, 323). This is the condition where legislators are perceived (and perceive themselves) as delegates carrying out the will of a majority of the people. What the people want, their representatives enact. The modern "majoritarian democracy" which ensues represents the gravest of dangers to freedom and the democratic process: in the name of the people, the law is whatever is enacted by the people's representatives. Legitimacy is replaced by legality. Restrictions on what governments can do are removed. The rule of legislators replaces rule of law (Sartori 1987, 323-326).

This rule of legislators is the majoritarian model of democracy in which representatives presumably enact the sovereign will of the people. It is the representative democratic implementation of the ancient assembled citizenry. It may suffer from the same lack of concern for protection of dissent as in the ancient assemblies, and majority tyranny may ensue. Furthermore, the will of the people cannot be implemented by majority voting techniques. Because of technical and 
mathematical properties, the will of the people cannot be discovered or expressed by majority rule voting (Riker 1982, 233-241). Nor is there any other voting method that can do so. If the sovereign will of the people cannot be discovered or expressed, then it cannot be the operating premise of a representative democracy to convert the will of the people into the law.

Even more basic, there may be no sovereign will of the people in the first place. The nature of public opinion is that there is rarely "a public opinion," a uniform position on a public issue which is the same among all groupings in a nation. Instead, there are many different publics with different positions, there are "publics' opinions." Moreover, only on specific issues affecting their self-interest do the publics have or express an opinion. Rather than the people's will, we have instead many competing publics' interests. The democratic process provides the mechanism to make binding collective decisions among such contending groups. Indeed, the proponents of the new American Constitution of 1787 believed justice itself to be this process which provided for reasoned contention among free persons (Ostrom 1987, 70).

An eighth concern is the thinking of some that we have tamed permanently the sword of government and that now we can turn that sword loose to tame the power of money (economic inequalities). To do so, we must unloose the sword of government to equalize socioeconomic resources (Sartori 1987, 389). To date, our experiences have been that once the sword is unleashed -- once constitutional rule of law restrictions are not in effect -- the sword is used arbitrarily by those who monopolize the binding decision-making. Sadly, the dream of equalization of resources not only does not occur, but the nightmare of political oppression -arbitrary use of political power (power over life and death) -- invariably takes its place (Sartori 1987, 392). The experience of the 20th century has been that once the sword of government is permitted to be monopolized by "the few" to redistribute socioeconomic resources for "the many," tyranny and poverty have inevitably followed.

The desire for widespread equalization of resources by government is, however, intrinsic to human nature and very strong. The various mass publics seek to utilize the modern "do-everything" state to provide security against life's needs, particularly against the situations generated by modern urban-industrial mass societies. These equalization actions range from the "equal starts" (redistributing resources to provide all with equal opportunity to become what we can) to state ownership. Equalization actions can consume an enormous amount of resources. If there are no surplus resources produced there is nothing to redistribute.

Economic liberty originally began as legal protection for western merchants against their monarchs' demands for funds, and against the feudal order's restrictions on economic activities (Riker 1982, 7). Since that time, economic freedom has fueled vast increases in production and distribution, as well as doubling the average life expectancy in the western democracies. If private property is eliminated there is no economic base for opposition to those persons 
who control the government monopoly on violence (Riker 1982, 7). But, having had freedom for so long in the western democracies that it is taken for granted, the temptation to risk freedom in pursuit of equality is very great. This is especially threatening in light of the tendency that western intellectuals have to undervalue, or perhaps not even understand, the benefits derived from liberal democracies (Sartori 1987, 388-392). Dispersion of control over production and distribution is as important to the propertyless as to the propertied (Sartori 1987, 378-379). Although liberalism and laissez faire are not the same (liberalism developed earlier and separately from commercialism and laissez faire), liberalism does sustain property-as-personal-safety (freedom). When the state owns all, "he who does not obey, shall not eat," as Sartori quotes Trotsky on the Stalinist state $(1987,360)$.

Yet, at the same time, inequalities affect citizens' capacities to exercise political equality -- to participate in decisions that affect them. Some who advocate the redistribution of resources vital to political equality emphasize that such is needed to protect the democratic process. They would use government to distribute resources to facilitate political equality while also protecting the primary political rights that comprise the democratic process, claiming that such distribution would in fact further the protection of such rights (Dahl 1989, 302-305).

Regardless of the motivation and outcome, if remedial actions are taken, resources necessarily are coerced from some and transferred to others. A critical freedom issue is who shall then equalize the equalizers? Rule of law constraints must remain in effect. Political freedom -- the freedom to act externally, not mere freedom to think secret thoughts within our own minds -- is obtained from law, from restrictions primarily upon government, but also upon other citizens to refrain from imposing their preferences by violence or other inappropriate forms of coercion (Sartori 1987, 299-310). And the citizenry should not be dispossessed of private property resources, or it cannot challenge those who would monopolize government's coercive power. Indeed, democracy itself depends upon a distribution of resources sufficient to sustain competition in the binding collective decision-making process. Some government-coerced redistribution may enhance political equality, but too much may impoverish economically and tyrannize politically. A competitive economic market structure seems to be a vital ingredient to develop and maintain adequate resource distribution. To date, successfully competitive market structures have been privately owned and publicly regulated (Sartori 1987, 392, 404-410).

A ninth problem area that requires attention is the ethical approach to life in modern democracies. Modern society embraces a utilitarian, self-serving ethic. For most of us, life has become the pursuit of pleasure. Individual and group actions are based upon short-term, self-interested calculations. Under such an ethic, it becomes irrational to engage in long-term calculations of democratic system maintenance because the benefits of such actions fall to future generations (Sartori 1987, 491-494). Politics consists of "getting," and we elect representatives to "get" for us. But -- to put the problem dramatically -- if we elect representatives 
who will legislate that we must be paid for not working, the time shall come when the system breaks down. How, then, is long-term democratic system maintenance to be obtained?

Civic virtue and concern for the common good are advocated. Yet there is serious doubt how much civic virtue has ever existed, and in modern mass societies where individuals and groups pursue self-interest, there is a question as to what the common good is, and how it can be known. In determining the common good, we are actually ascertaining whose good ought to be considered, and how this can best be done (Dahl 1989, 306). The best approach is to involve those persons whose interests are affected by the decisions, namely citizens.

Individuals as well as groups differ regarding what specific results they prefer, but they can agree that the common good consists of agreed upon procedures and institutions for the resolution of their disagreements: the democratic process itself becomes the essential common good (Dahl 1989, 306-307). Every citizen should have the opportunity for deciding their choices. The substantive outcome is whatever the democratic process -- that bundle of individual rights, institutions, and procedures -- has determined. The best chance that the substantive outcome will be reasonable and responsible is that in having the opportunity to participate (even if only by voting to choose who will decide), we exercise personal autonomy (self-made choices in our own best interest) through which we may develop an enlightened understanding of the consequences of alternative choices. Ultimately, we may develop moral autonomy -- that is, an understanding of the needs of others and of the democratic process itself, which is then incorporated into our self-directed actions (Dahl 1989, 308-311).

Finally, modern democracy has leadership problems. In "deciding the deciders" (Sartori 1987, 139), voters decide who governs more than what specific policies shall be. The quality of elected officials becomes, therefore, very important. It is necessary for elected officials to exercise leadership -- to assess and deliberate the various needs, interests, and preferences of the citizenry, within the long-term needs of the democratic process. But quality leadership in democracies is difficult in light of the tendency of the sheer numbers of citizens to vote as self-seeking interests. Not only does democracy itself tend to suppress the quality of candidates, but also interests and coalitions of interests are inherently motivated to eliminate competition and devise monopolies; i.e., to control elected officials in order to fix the rules and results of the process in one's favor. Nonetheless, so long as there exists a competitive social and economic structure with some dispersion of resources, there is both the motivation and the wherewithal to extract broad consent as to the nature of the collective decision-making process employed, as well as to the nature of the competition by which the deciders are chosen. Leadership then has a basis of understood convention as well as shorterterm electoral support from which to protect the democratic process against the inherent drive of humans and their groups to acquire private monopoly over the binding collective decision process. 


\section{Summary}

We must organize to obtain life's necessities and amenities. Because organization requires a binding collective decision-making process, decisions affecting the whole group will be required. A process for making these decisions is necessary and our innate needs compel us to seek a decision-making system in which our self-interests are met most effectively. Experience teaches that we must participate in the making of decisions that affect our interests, or our interests may not be considered by others making collective decisions.

Democracy is the name of the ideal that the people govern themselves, and of the implementation that we have devised for citizens to participate in the making of binding collective decisions. Direct democracy, a simple direct involvement in binding decisions, is possible when our group is small. Citizens directly participate in decisions affecting all of us, and we do whatever most of us want done. Such direct collective decision-making becomes impossible when our numbers increase. When there became too many of us to participate directly, we invented a way to participate indirectly. We select a few from among us to assemble together and make decisions that are binding upon all of us: representative democracy. We expect that our representatives will do what we would have done had we been present to decide for ourselves.

Our indirect participatory system -- our representative democracy -- is, however, a very different mechanism than was our direct participatory democracy. The latter operated within a small homogeneous population and culture. Originally democracy was a system where individual citizens were free to share equally in the making of binding collective decision-making within a small homogeneous community of similar interests. It was not concerned with individual freedom or the exercise of individual conscience, but with expressing the sovereign will of the people (Sartori 1987, 286-290). However, with the huge populations of modern nation-states, democracy must be a representative structure, which in practice is a system of competitive decision-making shared among diverse persons who are competing to codify their preferences as public policy. The modern democratic process is the result. That the process shall be both competitive and shared is assured by the package of individual rights, procedures, and institutions that both temper and perpetuate indirect democracy.

Indeed, this package of rights, procedures, and institutions is modern democracy. The common good is not, indeed cannot be, a substantive outcome, a particular policy desired by some citizens. Substantive results are specific preferences of the competing individuals or groups. The common good -- the shared value among all in a modern democracy -- is the democratic process itself. That which is shared by all, and which is most vital to all, is the rights, procedures, and institutions through which all may transmit their preferences and decide whose preferences become binding upon all (Dahl 1989, 172). Thus no prior claim to particular preferred substantive results can be made. To do so is to "fix" the 
outcome of the democratic process and, in so doing, to destroy the workings of the process.

Of course, the workings of the democratic process -- the rules -- cannot be too biased for or against any group, any more than outcomes can. The entire point of the process is to provide free and fair competition for public policies. This is why the particular distribution of resources among citizens is an important democratic concern, even though such cannot and should not be assured as the outcome of the process. We desire to make decisions that affect our lives, or at least to exercise meaningful and voluntary consent or dissent about such decisions. When we have the capacity to do such we will use that capacity, and this is what generates democracy. But for this capacity to exist the distribution of resources among citizens must be sufficient to enable them to demand successfully that the decision-making process provide for their input, and that the decision-making process operate on the basis of rules that process disagreements according to agreed-upon competitive procedures (Vanhanen 1990, 50-51). In the absence of more powerful emotive ties, belief in a common democratic process may be the shared value that produces modern national communities from diverse ethnic and/ or religious groups.

\section{Perils to Modern Democracy}

The basic peril to modern democracy is whatever would jeopardize the competitiveness of its procedures, rendering them unacceptably biased. Modern democracy is an agreed upon system of competition for the making of binding collective decisions. Modern democracy comes into existence because individuals and groups possess enough resources to insist upon participating in the binding collective decision-making process. Consequently, the great danger to modern democracy is whatever imperils the competitiveness of the binding collective decision-making process. Resources (economic, coercive, and informational) must be distributed adequately such that individuals and groups possess sufficient independence from each other and from their government.

Ironically, the first peril to this dispersion of resources is the intrinsic pressure to use government to equalize resources among the citizenry. For most self-interested citizens, government is readily perceived to be a coercive agent to extract resources from others: we may vote for our representatives to "get" for us resources produced by other citizens. In doing so, government may become the coercive agent of one set of citizens extracting disproportionate resources from others, a bias destructive of the democratic process. Or the government may dispossess the citizenry of the resources the citizenry needs to challenge the government and/or challenge other groups in the society. Without adequate distribution of private resources, citizens are politically powerless against the government and against each other. This leads to a second, related peril.

The second peril is that the democratic process itself is endangered by 
releasing government from its rule of law restraints to enable it to perform feats of societal equalization. The democratic process is a package of rules which we have agreed upon for competition in processing our disagreements over what we want the public policies to be. We have agreed upon these rules (individual rights, procedures, and institutions) because much experience has validated their reliability as protectors of our freedom of choice in decisions that affect us. (To be sure, these rights and procedures are in continual development and refinement.) Among the most vital of the rules of modern democracy is that government must be restrained by rule of law. What the institutions of government are, how they operate, and what they can do and cannot do are carefully circumscribed by law. This development of constitutional rule of law is what made modern democracy possible (Sartori 1987, 287, 383-386). Whenever the restraints on government have been released in this century to enable it to "do good" according to some redistributive dogma, the experience has been the same: government tyranny (arbitrary use of political power over life and death), and greater poverty created by the fatal embrace of a command economy by an all-powerful government (Sartori 1987, 392; Bates 1991, 24-25).

There is, however, a very different type of motivation for redistributing some resources. It comes from those who perceive that political equality requires some redistribution of socio-economic resources (Dahl 1989, 310-311). Participation in public decision-making at the very least provides opportunity to express one's own best interests and, in so doing, perhaps to develop an enlightened understanding of alternatives available and their consequences. Beyond this lies the opportunity to become a moral person: to understand and appreciate the needs of others and of the democratic process. Some redistribution of resources is needed to facilitate such development. So long as a competitive pluralist society and market-structured economy is augmented, not replaced, by such redistributions, the competitive structure of the modern democratic process is promoted (Sartori 1987, 399).

\section{Conclusions}

The mainstream democratic vision is a continuum of visions of what constitutes human freedom of choice and how best to construct the binding collective decision-making process to implement citizen participation in the making of decisions that affect all members of the association.

The democratic vision may be preferred both as a maximax strategy (as the best choice among favorable alternatives) and as a minimax strategy (as the least worst among unfavorable alternatives). Democracy is preferable as the maximax strategy because democracy permits all to participate and develop as individuals (Dahl 1989, 78). Modern systems are huge mass societies, vastly different than the homogeneous Greek societies (Dahl 1989, 19; Sartori 1987, 28). Diversity is inherent in the modern condition. As we pursue our individual 
interests, we disagree on what the collective decisions should be. Adversarial relationships ensue from diversity and conflict. The conduct of individual rights and freedoms develops to replace the consensus that the more homogeneous ancient Greek city-states had practiced (Dahl 1989,219-220). What becomes most crucial is the right of individuals to express their preferences and have their preferences given consideration by the collective decision-making process. Thus democracy becomes the logically preferable system because it permits the greatest number of individuals' preferences to be assessed and deliberated (Thorson 1962, 138-150).

The democratic vision may also be preferred because of a minimax strategy: it is the least noxious among alternative types of government (Dahl 1989,78). This, of course, is Winston Churchill's famous defense of democracy: that it is a terrible form of government until the alternatives are compared. Twentieth century experiences with totalitarianism and authoritarianism evince the view that liberal democracy is necessary to protect citizens from the arbitrary use of political power, that is, power over life and death (Sartori 1987, 323-386). Liberal democracy is the name given to a set of procedures and institutional arrangements that restrict governmental scope and limit what public officials can do. Liberal democracy permits us to be governed without being oppressed. It is organized and operated such that "no one may arrogate to himself unconditional and unlimited power" (Sartori 1987, 206). In accomplishing this, liberal democracy is one of humankind's greatest artifacts.

\section{In Defense of Liberal Democracy}

Liberal democracy is voters choosing, in free and fair elections contested by competing candidates, who shall fill public offices that, in turn, are restricted in authority by constitutional law. Liberal democracy rests upon the value placed on truth and correctness of information (Sartori 1987, 102). Liberal democracy requires that publics' opinions be freely formed and autonomous from government control or manipulation. However, liberal democracy does not require that voters be rational and well-informed, but merely that they choose those persons whom voters believe will provide the policies voters want in general -- and that they can replace, with their votes, those elected who do not seem to be doing what voters want. Liberal democracies provide the answer to what $\operatorname{Karl}$ Popper $(1988,20)$ has described as the most fundamental question of human political organization: "how can the state be constituted so that bad rulers can be got rid of without bloodshed?"

What western liberal democracies do is to provide a means "to be governed without being oppressed" (Sartori 1987, 160). And "no majority, no matter how large, ought to be permitted to abandon this rule of law" (Popper 1988, 21).

The capability to remove a government from office may not seem enough to those who ask more of democracy. Instead, some expect much more of 
institutionalized democratic participation: to identify shared human values, to develop our human potential for self-development -- these are lofty goals some have set for democracy. Citizens are hoped to be highly involved and highly knowledgeable concerning public affairs. The original democratic ideal of power to the people by their direct participation in public decision-making remains a powerful ideal. Hannah Arendt (1965, 236-240) considered it the "lost treasure" of the American revolution. It was "lost," she claimed, in the development of largescale representative institutions which only permit most citizens to participate on election day. Indeed, it could be argued that the federalist-antifederalist debate over ratification of the Constitution of 1787 was over the notion that smaller, more direct democratic institutions should be created rather than the large compound republic which was established (Allen, Lloyd, and Lloyd 1985, viii-xiv; Lewis 1967, 1-62).

But vast amounts of experience with representative democracy during the last 200 years provide overwhelming evidence that it is impossible to sustain among citizens the necessary commitment of time, interest, and knowledge to support widespread political participation over time (Sartori 1987, 110-120). In fact, pursuing direct participatory democracies when they are impossible to implement invariably results in domination by a small elite-vanguard of intensely motivated persons and groups. Because they are so certain of their preferences, intensely motivated activists are a great danger to democracy (Sartori 1987, 114). True believers cannot trust others, nor can they be trusted; and trust among political participants is important in the conduct of democratic operations (Dahl 1971, 150). Trust is provided by the guarantee of the rule of law and by a political culture that embraces trust. Ultimately, however, trust among political participants rests upon the possession of resources which support participation and thus assure a distribution of participants who have a self-interest in maintaining the competitive structure of the binding collective decision-making process.

Liberal democracies, for which "polyarchies" is another name (Dahl 1989, 218-219), are among humankind's greatest artifacts. Popper adds that they are worth dying for $(1988,21)$.

\section{Devising New Democracies}

The "waves of mobilization" (Tarrow 1991, 15-18) that have recently swept away many of those who had monopolized political power must now be institutionalized. After the barbed wire has been cut, the extremely formidable task of building the institutions and values to sustain democracy remains. Mass demonstrations are not democratic institutions. Political participation must be organized to permit citizens regular formulation and expression of their preferences, and to hold those temporarily elected to public office accountable to these preferences. Movement away from authoritarian regimes (e.g., Franco's Spain, Chiang's Taiwan, Park's South Korea) and away from totalitarian regimes (e.g., 
the USSR and Eastern Europe under CPSU hegemony) is underway. But there are no guarantees. While democracy is highly likely when resources are developed and reasonably distributed by a privately owned and publicly regulated marketstructure, it still depends upon human effort to devise a shared competitive political system.

The recent experience of centralized party-states and command economies in Eastern Europe, the USSR, and Third World nations stands in stark contrast to the freedoms and material prosperity of western-type democratic systems (see The Economist 11 May 1991, 11-12 \& 19 June 1991, 15-18). A vivid aphorism is the old World War I ditty, "How are you gonna keep'em down on the farm after they've seen Parie"? Yet, without established democratic values, practices, and institutions, when severe economic conditions arise there is still the ominous threat of populist "leaders" arising to champion governmental "guarantees" of food and jobs (Przeworski 1991, 20-24). We should not underestimate the willingness of humans to use force and fraudulent ideological justifications for monopolizing political power. On August 18, 1991, tanks rolled in Moscow and Leningrad in an attempted coup. Only the courage of the Soviet citizenry and that of democratic leaders prevented the coup from succeeding. The democratic vision of the freedom of individual choice provided the will, and the possession of some personal resources by the Soviet citizenry and their democratic leaders provided the wherewithal to oppose the tanks. In Stalin's time, such opposition would have been impossible: neither the vision of individual choice, nor the resources to demand a voice in collective decision-making, was then adequate.

Finally, neither majority rule nor the democratic process can establish which people are entitled to a political system of their own. Historical accident, war, population movement, ethno-racial, and religious factors all have influenced the placement of national boundaries. Whether cultural cleavages can be overcome by shared belief in the democratic process as the best way of adjusting such group differences is questionable, given the unfamiliarity with democratic discourse among those ruled until recently by authoritarians or totalitarians. Unless economic necessity hastens the realization that political union with others is preferable, the global movement toward democracy will not mean an end to violence and instability.

\section{REFERENCES}

Allen, W.B., Gordon Lloyd, and Margie Lloyd, eds. 1985. The Essential Anti-Federalist.

New York: University Press of America.

Arendt, Hannah. 1965. On Revolution. New York: Viking Press.

Barber, Benjamin R. 1984. Strong Democracy: Participatory Politics for a New Age. Berkeley, CA: University of California Press.

Bates, Robert H. 1991. The Economics of Transitions to Democracy. PS: Political Science and Politics 24: 24-29. 
Bay, Christian. 1970. The Structure of Freedom. Stanford, CA: Stanford University Press. Dahl, Robert A. 1990. After the Revolution. New Haven: Yale University Press. 1989. Democracy and its Critics. New Haven: Yale University Press. 1971. Polyarchy. New Haven: Yale University Press.

Economist, The. 19 June 1991. Freedom and Prosperity in Asia. 320: 15-18. 11 May 1991. From Marx to the Market. 319: 11-12.

Friedman, Milton I. and Rose Friedman. 1980. Free to Choose. NY: Harcourt, Brace, and Jovanovich.

Hayek, Friedrich. 1957. The Road to Serfdom. Chicago: University of Chicago Press. Lewis, John D., ed. 1967. Anti-Federalists Versus Federalists. San Francisco, CA: Chandler Publishing Co.

Nozick, Robert. 1974. Anarchy, State, and Utopia. New York: Basic Books.

Ostrom, Vincent. 1987. The Political Theory of a Compound Republic. Lincoln, NE: University of Nebraska Press.

Pennock, J. Roland. 1979. Democratic Political Theory. Princeton, NJ: Princeton University Press.

Popper, Sir Karl R. 1988. The Open Society and its Enemies Revisited. The Economist. 23 April: 19-22.

1963. The Open Society and Its Enemies. New York: Harper Torchbooks.

Przeworski, Adam. 1991. The "East" Becomes the "South"? The "Autumn of the People" and the Future of Eastern Europe. PS: Political Science and Politics 24: 20-24.

Rawls, John. 1971. A Theory of Justice. Cambridge, MA: Harvard University Press.

Riker, William H. 1982. Liberalism Against Populism. Prospect Hills, IL: Waveland Press, Inc.

Ryan, Jeffrey. 1992. Asymmetrical Interdependence and Democratization in Central America. Midsouth Political Science Journal 13 (forthcoming).

Sartori, Giovanni. 1987. Democracy Revisited, Vol. I-II. Chatham, NJ: Chatham House.

Simon, Yves. 1962. A General Theory of Authority. Notre Dame, IN: Notre Dame University Press.

Tarrow, Sidney G. 1991. "Aiming at a Moving Target": Social Science and the Recent Rebellions in Eastern Europe. PS: Political Science and Politics 24: 12-20.

Thorson, Thomas Landon. 1962. The Logic of Democracy. New York: Holt, Rinehart, and Winston.

Vanhanen, Tatu. 1990. The Process of Democratization: A Comparative Study of 147 States, 1980-88. New York: Crane Russak. 